\title{
Jakub Bryla*
}

\section{WPLYW UDZIALU W PODATKU DOCHODOWYM OD OSÓB FIZYCZNYCH NA REALIZACJĘ ZADAŃ WLASNYCH GÓRNOŚLĄSKO-ZAGEĘBIOWSKIEJ METROPOLII}

\section{Streszczenie}

Ustawa z dnia 9 marca 2017 roku o związku metropolitalnym w województwie śląskim jest pierwszą regulacją odnoszącą się do szeroko pojętej współpracy pomiędzy gminami konurbacji górnośląsko-zagłębiowskiej. Związek metropolitalny posiada szczególny charakter w systemie polskiego samorządu terytorialnego, ponieważ realizuje zadania własne oraz został objęty ustawowym systemem finansowania swojej działalności. Jednym ze źródeł dochodu jest udział we wpływach z podatku dochodowego od osób fizycznych. Jest to rozwiązanie nowatorskie, które dotychczas nie było stosowane przez polskiego ustawodawcę. Wobec powyższego konieczne jest przeprowadzenie analizy wpływu podatku dochodowego od osób fizycznych na finansowanie działalności metropolii w kontekście szans i zagrożeń oraz społecznych oczekiwań.

Słowa kluczowe: podatek dochodowy, Górnośląsko-Zagłębiowska Metropolia, konurbacja, samorząd terytorialny

\section{Wprowadzenie}

Dnia 7 kwietnia 2017 roku weszła w życie ustawa z 9 marca 2017 roku o związku metropolitalnym w województwie śląskim ${ }^{1}$. Przedmiotowa regu-

* mgr Jakub Bryła, Uniwersytet Śląski w Katowicach, adres e-mail: jakub.bryla@me.com. ORCID: 0000-0001-7187-2154

1 Ustawa z dnia 9 marca 2017 r. o związku metropolitalnym w województwie śląskim, Dz.U. z 2017 r., poz. 730, dalej: u.z.m.w.ś. 
lacja jest zwieńczeniem wieloletniego procesu kształtowania się statusu prawnego konurbacji górnośląskiej, a także odpowiedzią na społeczne oczekiwania kompleksowej regulacji sposobu funkcjonowania miast wchodzących w skład Górnośląsko-Zagłębiowskiej Metropolii² ${ }^{2}$. Obszar ten jest największą konurbacją w Polsce i drugą największą w Europie ${ }^{3}$, co powoduje, że funkcjonowanie tak złożonego organizmu wymaga dedykowanej konstrukcji prawnej. Na przestrzeni ostatnich trzydziestu lat podejmowano wiele inicjatyw mających na celu wzmocnienie współpracy pomiędzy samorządami wchodzącymi w skład konurbacji. Tytułem przykładu można podać następujące inicjatywy:

- utworzenie w 1991 roku Komunalnego Związku Komunikacyjnego Górnośląskiego Okręgu Przemysłowego, który do 2019 roku zajmował się organizacją transportu publicznego ${ }^{4}$,

- utworzenie Górnośląskiego Związku Metropolitalnego (związek międzygminny), którego celem była koordynacja działań w zakresie transportu, planowania przestrzennego, wspólnego zakupu energii elektrycznej przez miasta członkowskie ${ }^{5}$.

Ponadto śląskie środowisko naukowe opracowywało wiele rozwiązań uwzględniających szczególny charakter miast Górnego Śląska i Zagłębia Dąbrowskiego. Pierwszym kompleksowym projektem była idea powiatu metropolitalnego autorstwa B. Dolnickiego, J. Glumińskiej-Pawlic oraz C. Martysza ${ }^{6}$. Pomysł ten nie zyskał jednak uznania wśród poszczególnych rządów i w ten sposób z powiatu metropolitalnego końcowa koncepcja przybrała kształt niespotykanego dotąd związku metropolitalnego.

Powstanie związku metropolitalnego w województwie śląskim jest jedną z najbardziej znaczących innowacji w organizacji polskiego samorządu terytorialnego ${ }^{7}$. Innowacyjność rozumiana jako wprowadzenie unikalnego rozwiąza-

2 B. Dolnicki, R. Marchaj, Związek metropolitalny w województwie śląskim, „Samorząd Terytorialny" 2017, $\mathrm{nr} 7-8$, s. 5.

3 B. Dolnicki, Samorzad terytorialny, Warszawa 2016, s. 529.

4 W. Rymarczyk, 20 lat Komunikacyjnego Zwiąku Komunalnego Górnośląskiego Okręgu Przemysłowego, www.kzkgop.com.pl/public_media/fb/files/czasopisma/komunikacja/2011/kzk_32011.pdf (dostęp 1.04.2019).

5 www.gzm.org.pl (dostęp 1.04.2019).

6 B. Dolnicki, Koncepcja powiatu metropolitalnego, ,Samorząd Terytorialny” 2014, nr 7-8, s. 5-17.

7 R. Pyka, Górnośląsko-Zagłębiowska Metropolia jako innowacja w samorządzie terytorialnym. Szanse i wyzwania pierwszego w Polsce zwiazku metropolitalnego, „Studia Regionalne i Lokalne" 2018, nr 1 (71), s. 7. 
nia, odpowiadającego na zróżnicowane problemy i zmierzającego do poprawy życia społeczności lokalnych, stanowi odejście od przyjmowania zuniformizowanych w skali państwa rozwiązań prawnych dotyczących samorządü. Nowatorskim rozwiązaniem względem typowego związku komunalnego jest zagwarantowanie ustawą stałego źródła dochodu9 . W przepisie art. 52 u.z.m.w.ś. przewidziano 5\% udział związku metropolitalnego we wpływach z podatku dochodowego od osób fizycznych. Zapewnienie fiskalnych źródeł dochodu jest szczególnym rozwiązaniem, które uprawdopodobnia skuteczną realizację zadań własnych Metropolii Górnośląsko-Zagłębiowskiej. Tak skonstruowany status prawny konurbacji górnośląskiej jest przeciwieństwem dotychczasowych rozwiązań, które cechowały się dobrowolnością przystąpienia, finansowania i działania poszczególnych miast ${ }^{10}$.

W niniejszym opracowaniu zostanie przedstawiona analiza wpływu udziału Górnośląsko-Zagłębiowskiej Metropolii w podatku dochodowym od osób fizycznych na realizację zadań własnych związku w kontekście oczekiwań samorządowców oraz mieszkańców.

\section{Górnośląsko-Zagłębiowska Metropolia - specyfika, stan faktyczny}

Prawidłowa analiza tematyki finansowania działalności Górnośląsko-Zagłębiowskiej Metropolii musi zostać poprzedzona omówieniem jej specyfiki, gdyż charakter miast wchodzących w skład związku jest fundamentem powstałej regulacji prawnej. W uzasadnieniu do u.z.m.w.ś. odwołano się do specyfiki regionu, który jest jednym z najlepiej ukształtowanych obszarów funkcjonalnych $^{11}$. Jak już zostało na wstępie podkreślone, miasta Metropolii są przykładem typowej konurbacji, czyli zespołem miast o zbliżonej wielkości, bez wyraźnie wyodrębnionego miasta centralnego ${ }^{12}$. Jej cechami szczególnymi są: bardzo

8 J. Przywojska, I. Warwas, Innowacje w zarządzaniu publicznym i polityce społecznej. Wprowadzenie do problematyki, „Przedsiębiorczość i Zarządzanie” 2016, t. XVII, z. 4, cz. 2, s. 5-14.

9 R. Pyka, op. cit., s. 12.

10 B. Dolnicki, Koncepcja ustawy o powiecie metropolitalnym Aglomeracji Górnoślaskiej, w: Miasta, aglomeracje, metropolie w nurcie globalnych przemian, red. K. Kuć-Czajkowska, M. Sidor, Lublin 2014, s. 201.

11 Rządowy projekt ustawy o związku metropolitalnym w województwie śląskim, www.sejm.gov.pl/Sejm8.nsf/PrzebiegProc.xsp?nr=1211 (dostęp 2.04.2019).

12 A. Szajnowska-Wysocka, Podstawy zorganizowania miast konurbacji górnoślaskiej, Katowice 1995 , s. 10-17. 
duża gęstość zaludnienia, intensywność zabudowy, rozbudowana infrastruktura drogowa oraz sieć połączeń komunikacji publicznej i duża codzienna migracja pomiędzy miastami ${ }^{13}$. Niniejsza struktura powoduje często powielanie zadań realizowanych przez sąsiadujące ze sobą samorządy. Jest to sytuacja, w której zintegrowane przestrzennie miasta wykonują ten sam rodzaj zadań publicznych, jak np. dostarczenie wody, organizacja transportu publicznego. $Z$ uwagi na te działania, budżety poszczególnych jednostek są narażone na brak racjonalności w wydatkowaniu środków publicznych ${ }^{14}$. Rozwiązaniem niniejszego problemu jest ścisła współpraca poprzez zawiązywanie m.in. związków międzygminnych, spółek handlowych. W istocie konurbacja górnośląska jest obszarem, na terenie którego występują z jednej strony problemy typowe dla największych miast Polski, a zarazem pojawiają się potrzeby na poziomie najmniejszych gmin ${ }^{15}$. Dlatego też od lat pojawiały się głosy o konieczności stworzenia regulacji, która będzie odpowiedzią na pojawiające się problemy i potrzeby miast konurbacji. Brak wyraźnej współpracy między gminami i powiatami doprowadził do marginalizacji w zestawieniu z mniejszymi ośrodkami, takimi jak Kraków czy Wrocław. Jak podkreśla D. Rynio, inwestorzy, analizując umiejscowienie inwestycji, biorą pod uwagę wiele elementów, takich jak relacje polityczne, gospodarcze i warunki zakładania działalności w docelowym obszarze ${ }^{16}$. Trwałość sytuacji polityczno-gospodarczej jest minimalnym warunkiem lokalizacji inwestycji. Istotna jest również stabilizacja na niższych poziomach oraz długookresowość programowania rozwoju przestrzeni metropolii ${ }^{17}$.

Wobec powyższego, na podstawie u.z.m.w.ś., z początkiem 2018 roku powołana została Górnośląsko-Zagłębiowska Metropolia, składająca się z 26 gmin miejskich, 2 gmin miejsko-wiejskich oraz 13 gmin wiejskich. Liczy ona w sumie 2279560 mieszkańców $^{18}$. Metropolia posiada organ stanowiący i kon-

13 B. Dolnicki, R. Marchaj, op. cit., s. 5.

14 B. Dolnicki, Założenia ustawy o powiecie metropolitalnym Górnego Śląska i Zagłębia, w: Formy współdziałania jednostek samorządu terytorialnego, red. idem, Warszawa 2012, s. 86-88.

15 J. Bryła, Metropolia Górnoślasko-Zagłębiowska - szanse i zagrożenia, Ogólnopolska Konferencja Naukowa pt. Aktualne problemy prawa i samorządu terytorialnego, Wydział Prawa i Administracji Uniwersytetu Warmińsko-Mazurskiego w Olsztynie, Olsztyn 2018.

16 D. Rynio, Atrakcyjność lokalizacji inwestycji zagranicznych w metropolii, w: Innowacyjna metropolia, konkurencyjny region, red. M. Słupińska, Łódź 2010, s. 105.

17 Ibidem.

18 M. Góralczyk, E. Panasiuk, M. Przybyła, Statystyczny obraz Górnośląsko-Zagłębiowskiej Metropolii w 2017 r., Katowice 2018, s. 10. 
trolny w postaci Zgromadzenia Górnośląsko-Zagłębiowskiej Metropolii, które składa się z delegatów gmin wchodzących w skład związku, po jednym z każdej gminy. Organem wykonawczym jest 5-osobowy zarząd, wybierany przez zgromadzenie. Istotne jest, że stworzono związek, który nie wpisuje się w definicję typowego związku międzygminnego, ani tym bardziej jednostki samorządu terytorialnego ${ }^{19}$. Metropolia ta posiada trzy cechy samorządu terytorialnego, które należy wyróżnić:

- przedmiot - wykonywanie zadań publicznych,

- nadzór - związek poddany został nadzorowi na podstawie przepisów ustawy o samorządzie województwa ${ }^{20}$,

- zadania $^{21}$.

Kwestia zadań własnych uregulowana została w przepisie art. 12 u.z.m.w.ś., który wprowadza do polskiego systemu prawa samorządu terytorialnego nowatorskie rozwiązanie polegające na przyznaniu związkowi zadań własnych. W ustawie podkreślono, że Metropolia odpowiedzialna jest w szczególności za:

- kształtowanie ładu przestrzennego,

- kształtowanie rozwoju społecznego i gospodarczego obszaru związku metropolitalnego,

- planowania, koordynacji integracji oraz rozwoju publicznego transportu zbiorowego, w tym transportu drogowego, kolejowego oraz innego transportu szynowego, a także zrównoważonej mobilności miejskiej,

- metropolitalnych przewozów pasażerskich,

- współdziałania w ustalaniu przebiegu dróg krajowych i wojewódzkich na obszarze związku metropolitalnego,

- promocji związku metropolitalnego i jego obszaru.

Analogicznie do rozwiązań przyjętych w ustawach ustrojowych samorządu terytorialnego, zapewniono dodatkowe środki finansowe konieczne dla realizacji nowych zadań przekazanych związkowi metropolitalnemu w drodze ustawy ${ }^{22}$. Aspekt ten jest jedną z najbardziej oczekiwanych zmian, która w sposób realny może przełożyć się na wzrost atrakcyjności regionu.

19 B. Dolnicki, R. Marchaj, op. cit., s. 7.

20 Ustawa z dnia 5 czerwca 1998 r. o samorządzie województwa (Dz.U. z 2019 r., poz. 512).

21 M. Jastrzębska, Finanse jednostek samorządu terytorialnego, Warszawa 2012, s. 15.

22 T. Bąkowski, R. Gajewski, J. Szlachetko, K. Ważny, Ustawa o związkach metropolitalnych. Komentarz, Warszawa 2016, s. 155. 


\section{Finanse i dochody Górnośląsko-Zagłębiowskiej Metropolii}

W rozdziałach 6 i 7 u.z.m.w.ś uregulowano zagadnienia dotyczące finansów oraz dochodów związku metropolitalnego. Wykładnia powyższych przepisów skłania do stwierdzenia, że przyjęto rozwiązania analogiczne do tych uregulowanych w ustawach samorządowych. Górnośląsko-Zagłębiowska Metropolia posiada osobowość prawną i, zgodnie z przepisem art. 44 u.z.m.w.ś., samodzielnie prowadzi swoją gospodarkę finansową na podstawie uchwały budżetowej. Samodzielność finansowa samorządu terytorialnego przejawia się w wielu aspektach, a jej źródła należy dopatrywać w Konstytucji Rzeczypospolitej ${ }^{23}$. W przepisie art. 16 ust. 2 ustawy zasadniczej wskazano bowiem, że zadania publiczne, powierzone samorządowi terytorialnemu, mają być wykonywane we własnym imieniu i na własną odpowiedzialność, natomiast w przepisie art. 167 ust. 1 zagwarantowano jednostkom samorządu terytorialnego udział w dochodach publicznych odpowiednio do przypadających im zadań. W kontekście związku metropolitalnego oczywiste jest, że jego funkcjonowanie nie bazuje wprost na przepisach Konstytucji RP, ale przyjęta konstrukcja opierająca się na aktach regulujących ustrój samorządu terytorialnego w sposób pośredni wywodzi się z treści ustawy zasadniczej24. Ponadto samodzielność finansowa zagwarantowana jest w art. 45 u.z.m.w.ś., który stanowi, że przekazywanie związkowi metropolitalnemu nowych zadań może nastąpić tylko w drodze ustawy wraz z zapewnieniem koniecznych do ich realizacji środków finansowych w postaci zwiększenia dochodów ${ }^{25}$. Podstawą gospodarki finansowej związku jest budżet, za którego prawidłowe wykonanie odpowiada zarząd ${ }^{26}$. Organ wykonawczy posiada wyłączne prawo do:

- zaciągania zobowiązań mających pokrycie w ustalonych w uchwale budżetowej kwotach wydatków, w ramach upoważnień udzielonych przez zgromadzenie,

- emitowania papierów wartościowych, w ramach upoważnień udzielonych przez zgromadzenie,

23 Konstytucja Rzeczypospolitej Polskiej z dnia 2 kwietnia 1997 r. (Dz.U. z 1997 r., nr 78, poz. 483), dalej: Konstytucja RP.

24 T. Bąkowski, R. Gajewski, J. Szlachetko, K. Ważny, op. cit., s. 152.

25 M. Ofiarska, Problematyka budżetowa w ustawie o zwiazkach metropolitalnych, „Prawo Budżetowe Państwa i Samorządu” 2016, nr 2 (4), s. 8.

26 Art. 46 u.z.m.ś. 
- dokonywania wydatków budżetowych,

- zgłaszania propozycji zmian w budżecie związku metropolitalnego,

- dysponowania rezerwą budżetu związku metropolitalnego,

- blokowania środków budżetowych w przypadkach określonych ustawą ${ }^{27}$.

Z punktu widzenia tworzenia budżetu najistotniejsze są przepisy art. 51-54 u.z.m.w.ś., które w sposób szczegółowy określają dochody związku metropolitalnego. Wśród nich przewidziano m.in. udział we wpływach z podatku dochodowego od osób fizycznych zamieszkałych na obszarze związku metropolitalnego ${ }^{28}$. Innowacyjność w postaci określenia zadań własnych związku metropolitalnego pociągnęła za sobą nowatorskie sformułowanie sposobów finansowania jego działalności. Dotychczas żadna z inicjatyw jednoczących gminy i powiaty konurbacji nie przewidywała uzyskiwania środków z budżetu państwa. Finansowanie działalności KZK GOP lub GZM opierało się na wnoszeniu składek członkowskich uczestników związku ${ }^{29}$. Obecnie, zgodnie z treścią przepisu art. 52 ust. 1 u.z.m.w.ś., udział związku metropolitalnego w podatku dochodowym od osób fizycznych wynosi 5\% (w roku rozpoczęcia działalności poziom ten wynosił 0,2\%). W tym miejscu należy zaznaczyć, że w przepisie art. 52 ust. 2-4 u.z.m.w.ś. wskazano zasady obliczenia kwoty, natomiast w ust. 5 zawarto odniesienie do przepisu art. 11 ust. 2-3 ustawy o dochodach jednostek samorządu terytorialnego, który wprowadza zasady przekazywania środków stanowiących dochody

\section{Ibidem.}

28 Art. 51 u.z.m.ś. jako źródła dochodów Górnośląsko-Zagłębiowskiej Metropolii wymienia:

- udział we wpływach z podatku dochodowego od osób fizycznych zamieszkałych na obszarze związku metropolitalnego,

- składki od gmin wchodzących w skład związku metropolitalnego,

- dochody uzyskiwane przez jednostki budżetowe związku metropolitalnego oraz wpłaty od zakładów budżetowych związku metropolitalnego,

- dochody z majątku związku metropolitalnego,

- spadki, zapisy i darowizny na rzecz związku metropolitalnego,

- odsetki od pożyczek udzielanych przez związek metropolitalny, o ile odrębne przepisy nie stanowia inaczej,

- odsetki od nieterminowo przekazywanych należności stanowiących dochody związku metropolitalnego,

- odsetki od środków finansowych gromadzonych na rachunkach bankowych związku metropolitalnego, o ile odrębne przepisy nie stanowią inaczej,

- dotacje z budżetu państwa,

- dotacje z budżetów jednostek samorządu terytorialnego,

- inne dochody należne związkowi metropolitalnemu na podstawie odrębnych przepisów.

29 Obwieszczenie Wojewody Śląskiego z dnia 12 czerwca 2015 r. w sprawie ogłoszenia zmiany statutu Komunikacyjnego Związku Komunalnego Górnośląskiego Okręgu Przemysłowego w Katowicach, poz. 3232. 
z tytułu udziału we wpływach z podatku dochodowego od osób fizycznych, które podlegają przekazaniu z centralnego rachunku bieżącego państwa na rachunki budżetów właściwych jednostek samorządu terytorialnego ${ }^{30}$.

Poddając analizie przepisy dotyczące partycypowania związku w podatku dochodowym od osób fizycznych, należy dokonać wykładni użytego w przepisie art. 51 pkt. 1 sformułowania „od osób fizycznych zamieszkałych na terenie związku metropolitalnego". Omawiany podatek regulowany jest przez ustawę o podatku dochodowym od osób fizycznych ${ }^{31}$. W przepisie art. 3 ust. 1 u.p.d.o.f. określony został nieograniczony obowiązek podatkowy dla osób fizycznych mających miejsce zamieszkania na terytorium Rzeczypospolitej Polskiej bez względu na miejsce położenia źródeł przychodów. W ust. 2 wspomnianego artykułu doprecyzowano, że osobą fizyczną mającą miejsce zamieszkania na terytorium Rzeczypospolitej Polskiej jest podmiot, który posiada na jej terytorium centrum interesów życiowych lub gospodarczych (ośrodek interesów życiowych) lub przebywa dłużej niż $183 \mathrm{dni}$ w roku podatkowym. Istotna jest również instytucja ograniczonego obowiązku podatkowego dla osób niemających miejsca zamieszkania na terenie Rzeczpospolitej Polskiej, które podlegają obowiązkowi tylko od dochodów (przychodów) osiągniętych na jej terenie ${ }^{32}$.

Określenie grupy osób obowiązanych do uiszczenia podatku ma ogromne znaczenie, szczególnie w dobie swobody przepływu osób między państwami ${ }^{33}$. $\mathrm{Na}$ fakt ten wskazują również przedstawiciele Górnośląsko-Zagłębiowskiej Metropolii, którzy w uzasadnieniu do Wieloletniej Prognozy Finansowej Górnośląsko-Zagłębiowskiej Metropolii na lata 2017-2020 podkreślili dużą zmienność kwoty pochodzącej z udziału w podatku dochodowym, spowodowanej zmniejszaniem się liczby mieszkańców zamieszkujących teren związku³. Zgodnie z przyjętym modelem finansowania Metropolia będzie uzyskiwać 5\% kwoty uzyskanej od osób fizycznych, które posiadają centrum interesów osobistych lub gospo-

30 Ustawa z dnia 13 listopada 2013 r. o dochodach jednostek samorządu terytorialnego (Dz.U. z 2019 r., poz. 525), dalej: u.d.j.s.t.

31 Ustawa z dnia 26 lipca 1991 r. o podatku dochodowym od osób fizycznych (Dz.U. z 2019 r., poz. 303), dalej: u.p.d.o.f.

32 Art. 3 ust. 2 a u.p.d.o.f.

33 S. Moczko-Wdowczyk, M. Mucha, Podatek dochodowy od osób fizycznych. Komentarz, Warszawa 2005.

34 Wieloletnia prognoza finansowa Górnośląsko-Zagłębiowskiej Metropolii, https://bip. katowice.eu/Lists/Dokumenty/Attachments/103371/w\%20sprawie\%20uchwalenia\%20Wieloletniej\%20Prognozy\%20Finansowej\%20Górnośląsko\%20\%20Zagłębiowskiej\%20Metropolii\%20 na\%201ata\%202017\%20-\%202020.pdf (dostęp 2.04.2019). 
darczych lub przebywają przynajmniej 183 dni na terenie gmin wchodzących w skład związku ${ }^{35}$. Istotne jest stosowanie powyższych kryteriów rozłącznie, a zatem należy uznać, że posiadanie choćby jednego z nich oznacza posiadanie tu miejsca zamieszkania ${ }^{36}$. Pogląd ten jest tożsamy z orzecznictwem sądów administracyjnych, zgodnie z którym miejsce zamieszkania definiuje się jako centrum osobiste lub gospodarcze wyznaczone na podstawie związków osobistych lub ekonomicznych, wśród których istotne są m.in.: więzi rodzinne, towarzyskie, zatrudnienie, działalność polityczna, kulturalna, miejsce wykonywania działalności zarobkowej, źródła dochodów, posiadane inwestycje, majątek nieruchomy i ruchomy, zaciągnięte kredyty, konta bankowe, miejsce, z którego osoba zarządza swoim mieniem ${ }^{37}$.

Tak rozumiany obowiązek podatkowy od dochodów osób fizycznych jest podstawą budżetu Górnośląsko-Zagłębiowskiej Metropolii. Jest to najistotniejszy element budżetu warunkujący w zasadniczym stopniu poziom zaspokojenia potrzeb społeczności lokalnej w związku z realizacją zadań własnych Metropoliii ${ }^{38}$. Autorzy pierwszej Wieloletniej Prognozy Finansowej założyli, że od 2018 roku 90\% wszystkich dochodów będzie pochodzić z udziału w podatku dochodowym i będzie wynosić 319143 916,00 PLN, przy łącznej kwocie dochodów wynoszącej 351858 308,00 PLN. Opisywany dokument powstał w momencie składania wniosku o utworzenie Metropolii, a zatem nie były jeszcze znane władze, plany, a także model całkowitego finansowania działalności związku. W grudniu 2018 roku przyjęta została zaktualizowana Wieloletnia Prognoza Finansowa Górnośląsko-Zagłębiowskiej Metropolii na lata 2019-2030, która zakłada znacznie większy budżet związku, a tym samym spadek udziału kwoty z podatku dochodowego od osób fizycznych w kwocie dochodów ogółem ${ }^{39}$.

W 2019 roku przewidziano wpływ z udziału w podatku dochodowym od osób fizycznych w kwocie 372271 962,00 PLN przy ogólnym dochodzie na poziomie 1218664 634,00 PLN, natomiast dla 2030 roku przewidziano budżet w wysokości

35 K. Serwińska, J. Narkiewicz-Tarłowska, PIT. Komentarz praktyczny, Warszawa 2014.

36 Interpretacja indywidualna Dyrektora Izby Skarbowej w Łodzi z dnia 7 lutego 2012 r., IPTPB2/415-650/11-4/MP, Legalis.

37 Wyrok WSA w Szczecinie z dnia 15 lutego 2018 r., I SA/Sz 1063/17.

38 Treść z uzasadnienia do Wieloletniej Prognozy Finansowej Górnośląsko-Zagłębiowskiej Metropolii na lata 2017-2020.

39 Uchwała Zgromadzenia Górnośląsko-Zagłębiowskiej Metropolii z dnia 18 grudnia $2018 \mathrm{r}$. w sprawie uchwalenia Wieloletniej Prognozy Finansowej Górnośląsko-Zagłębiowskiego Metropolii na lata 2019-2030, nr XIII/78/2018. 
1670980 628,00 PLN, w tym 519106 318,00 PLN z udziału w podatku dochodowym od osób fizycznych. Wzrost budżetu względem pierwszej prognozy finansowej spowodowany jest ustaleniem składek członkowskich na podstawie przepisu art. 53 u.z.m.w.ś., otrzymaniem mienia, które generuje dochody, otrzymaniem dotacji oraz środków przeznaczonych na dotacje. Jednak w aspekcie udziału w podatku dochodowym od osób fizycznych przedstawiciele Metropolii w uzasadnieniu podkreślili, że prognoza jest obarczona znacznym ryzykiem błędu, wynikającym między innymi ze zmienności dynamiki procesów gospodarczych w kraju i poza nim, a także ze zjawisk mających wpływ na gospodarkę w sferze polityki, zmian legislacyjnych ${ }^{40}$. Obecnie przyjmuje się, że największym źródłem dochodów będą wpłaty gmin członkowskich składających się z części stałej, powiązanej ze wspomnianym udziałem w podatku dochodowym oraz części zmiennej, uzależnionej od ilości i zakresu przekazywanych przez gminy zawiązkowi metropolitalnemu zadań i rzeczywistych kosztów ich realizacji ${ }^{41}$. Kolejnym pod względem wielkości wpływem będzie udział w podatku dochodowym od osób fizycznych. Jego wysokość ustalono na podstawie prognozowanego wzrostu produktu krajowego brutto oraz wzrostu wynagrodzeń ${ }^{42}$.

Przedstawiony system finansowania działalności Górnośląsko-Zagłębiowskiej Metropolii stanowi realizację postulatów samorządowców i jest sporą innowacją, lecz z drugiej strony należy podkreślić, że kwota ok. 350 mln złotych jest dalece niewystarczająca i nie wpłynie znacząco na liczbę inwestycji przeprowadzanych na obszarze zamieszkiwanym przez blisko $2,8 \mathrm{mln}$ mieszkańców ${ }^{43}$. Dla porównania likwidowany KZK GOP w 2018 roku dysponował budżetem opiewającym na kwotę $660 \mathrm{mln}$ złotych ${ }^{44}$. Przedstawiona sytuacja nie jest niczym szczególnie nowym w systemie finansowania jednostek samorządu terytorialnego, gdyż jak podkreśla J. Glumińska-Pawlic, poziom środków przekazywanych poszczególnym samorządom jest niewystarczający, a jednostki - ze względu na ich zróżnicowania - nie zawsze są w stanie poradzić sobie z realizacją zadań $^{45}$. Związek metropolitalny, chociaż nie jest jednostką samorządu terytorial-

40 Ibidem.

41 R. Pyka, op. cit., s. 12.

42 Ibidem.

43 Ibidem.

44 Uchwała Zarządu KZK GOP z dnia 7 listopada 2017 r. w sprawie przyjęcia projektu uchwały Zgromadzenia KZK GOP w sprawie planu finansowego na rok 2018, nr 63/2017.

45 J. Glumińska-Pawlic, w: Ustawa o samorzadzie powiatowym. Komentarz, red. B. Dolnicki, Warszawa 2007, komentarz do art. 56, pkt 6. 
nego, dotknięty jest takim samym problemem braku wystarczających środków finansowych jak gminy, powiaty i województwa. Potwierdzeniem tej tezy są chociażby społeczne oczekiwania względem Metropolii. Badania dowodzą, że 63\% mieszkańców oczekuje zwiększenia inwestycji w infrastrukturę drogową, 52,2\% oczekuje zmian w systemie transportu miejskiego, a zatem tylko dwie najbardziej popularne odpowiedzi wskazują na najbardziej kosztowne zadania własne związku ${ }^{46}$. Celem zobrazowania wielkości dwóch najbardziej kosztownych sfer działalności Metropolii należy zasygnalizować, że sama sieć linii tramwajowych składa się z $181 \mathrm{~km}$ oraz 336 wagonów $^{47}$, natomiast koszt budowy ostatniego odcinka Drogowej Trasy Średnicowej łączącej Katowice z Gliwicami opiewał na blisko miliard złotych ${ }^{48}$.

Zgodnie z przedstawionymi danymi nie sposób nie zauważyć, że kwota otrzymywana z udziału w podatku dochodowym od osób fizycznych jest niewystarczająca i jej zadaniem jest raczej stworzenie odpowiedniego klimatu do współpracy pomiędzy samorządami, aniżeli faktyczne przełożenie na liczbę lub wielkość inwestycji miękkich lub infrastrukturalnych. Pozytywnie należy ocenić powiązanie części stałej składek członkowskich z planowanymi na rok budżetowy dochodami z tytułu udziału gminy we wpływach z podatku dochodowego od osób fizycznych i udziału gminy we wpływach z podatku dochodowego od osób fizycznych, o którym mowa w przepisie art. 4 ust. 2 u.d.j.s.t. Uzyskany w ten sposób automatyzm określania wysokości składki członkowskiej wraz z brakiem procedury wystąpienia ze związku jest rozwiązaniem, które w przyszłości może uchronić Górnośląsko-Zagłębiowską Metropolię przed impulsywnym działaniem poszczególnych włodarzy, tak jak to miało miejsce w KZK $\mathrm{GOP}^{49}$ czy też w $\mathrm{GZM}^{50}$.

46 G. Gawroński, M. Kłoskowicz, A. Stawowa, A. Wycisk, A. Zygmunt, Metropolia w świetle opinii mieszkańców Górnośląskiego Związu Metropolitalnego, w: Sposób na Metropolię. Idee a społeczne oczekiwania wobec projektu utworzenia śląsko-zagłębiowskiej metropolii, red. R. Pyka, Katowice 2010, s. 61.

47 Z. Danyluk, P. Nadolski, K. Soida, Tramwaje górnośląskie. Tom 2. Tramwaje katowickie po 1945 roku, Katowice 2012, s. 56.

48 Otwarcie Drogowej Trasy Średnicowej już w marcu!, https://conadrogach.pl/informacje/ gliwice-otwarcie-drogowej-trasy-srednicowej-juz-w-marcu.html (dostęp 3.04.2019).

49 Bytom wystapit $z$ KZK GOP, http://infobus.pl/bytom-bytom-wystapil-z-kzk-gop_ more_7181.html (dostęp 3.04.2019).

50 Jaworzno wystęuje z GZM. Radni przyjęli uchwatę w sprawie wyjścia z metropolii, http://katowice.wyborcza.pl/katowice/1,35063,20291839,jaworzno-wystepuje-z-gzm-radni-przyjeli-uchwale-w-sprawie-wyjscia.html (dostęp 3.04.2019). 


\section{Podsumowanie}

Powstanie Górnośląsko-Zagłębiowskiej Metropolii bez wątpienia jest wydarzeniem przełomowym w historii miast konurbacji. Jest to pierwszy akt w powojennej historii Polski odwołujący się do unikalnego charakteru regionu. Autorzy ustawy tworzącej związek metropolitalny inspirowali się rozwiązaniami znajdującymi się w ustawach samorządowych, a także korzystali z własnych doświadczeń przy tworzeniu związków międzygminnych. W konsekwencji powstała nowatorska instytucja spełniająca trzy z czterech cech samorządu terytorialnego, $\mathrm{z}$ własnymi zadaniami i ustawowo określonym modelem finansowania działalności. Przyznanie Metropolii udziału we wpływach z podatku dochodowego od osób fizycznych jest z pewnością rozwiązaniem korzystniejszym od modelu uiszczania składek członkowskich na rzecz podmiotu. Wątpliwości może jednak budzić poziom udziału w podatku, ponieważ w przeliczeniu na rzeczywisty wpływ do budżetu $350 \mathrm{mln}$ złotych okazuje się kwotą, która nie jest w stanie rozwiązać największych problemów miast Metropolii. Ponadto warto podkreślić, że kwota ta na przestrzeni lat może się zmieniać ze względu na migracje mieszkańców, a także polityczne programy, takie jak zerowy PIT dla młodych osób ${ }^{51}$. Wobec powyższego w opinii autora procentowy udział w omawianym podatku powinien wynosić przynajmniej równowartość ostatniego budżetu KZK GOP, tj. 700 mln złotych, a zatem postulatem de lege ferenda jest zwiększenie udziału w podatku PIT do $10 \%$.

Pomijając kwestię zmienności kwoty uzyskanej z udziału w podatku dochodowym od osób fizycznych, należy przyjąć, że ustawowe uregulowanie źródeł dochodów pozwala Metropolii na szybsze zgromadzenie odpowiednich środków finansowych niezbędnych do kreowania rozwoju regionalnego oraz zaspokajania potrzeb społeczności lokalnej ${ }^{52}$. Posiadanie stabilnej podstawy finansowej przyczynia się również do zwiększenia możliwości kredytowych związku ${ }^{53}$. Dopełnieniem przepisu art. 52 u.z.m.w.ś. jest regulacja z przepisu art. 53 u.z.m.w.ś., określająca sposób obliczania części stałej składki członkowskiej. Niniejsze rozwiązanie ma w istocie zapobiegać manipulacjom wysokościami kwot wpła-

51 Minister finansów ogłasza szczegóły obniżki PIT, www.forbes.pl/gospodarka/obnizka-pitkiedy-wejdzie-w-zycie-na-czym-bedzie-polegac/ljm5q1w (dostęp 3.04.2019).

52 A. Kozera, Samodzielność finansowa metropolii w Polsce w latach 2007-2015, „Studia Regionalne i Lokalne" 2018, nr 1 (71), s. 83.

53 S. Juszczyk, Zdolność kredytowa w ocenie banku na przykładzie małych i średnich przedsiębiorców, www.wne.sggw.pl/czasopisma/pdf/EIOGZ_2008_nr66_s17.pdf (dostęp 3.04.2019). 
canymi na rzecz Górnośląsko-Zagłębiowskiej Metropolii przez przedstawicieli poszczególnych gmin. W ten sposób zbudowany budżet może być podstawą do dalszych starań w pozyskiwaniu środków zewnętrznych od podmiotów prywatnych, państwowych oraz unijnych na takie projekty, jak np. kolej metropolitalna ${ }^{54}$.

Zaletą wskazanego modelu finansowania działalności jest również możliwość zainteresowania szerszego grona odbiorców sprawami Metropolii. Fakt partycypowania we wpływach z podatku dochodowego od osób fizycznych jest okazją do wskazania, ale także udowodnienia, że środki pochodzące od mieszkańców są wydatkowane w sposób transparentny oraz celowy. Zabieg ten jest niezbędny do wytworzenia poczucia przynależności do nowo powstałej instytucji.

Podsumowując, należy stwierdzić, że udział Metropolii w podatku dochodowym od osób fizycznych nie jest wystarczający na pokrycie kosztów realizacji wszystkich zadań własnych określonych ustawą, niemniej stworzenie innowacyjnego rozwiązania w strukturze samorządu terytorialnego umożliwiło zakończenie wieloletniej debaty na temat statusu oraz sposobu finansowania współpracy pomiędzy miastami konurbacji.

\section{Literatura}

Bąkowski T., Gajewski R., Szlachetko J., Ważny K., Ustawa o związach metropolitalnych. Komentarz, Warszawa 2016.

Danyluk Z., Nadolski P., Soida K., Tramwaje górnośląskie. Tom 2. Tramwaje katowickie po 1945 roku, Katowice 2012.

Dolnicki B., Koncepcja ustawy o powiecie metropolitalnym Aglomeracji Górnoślaskiej, w: Miasta, aglomeracje, metropolie w nurcie globalnych przemian, red. K. Kuć-Czajkowska, M. Sidor, Lublin 2014.

Dolnicki B., Założenia ustawy o powiecie metropolitalnym Górnego Ślaska i Zagłębia, w: Formy współdziałania jednostek samorządu terytorialnego, red. B. Dolnicki, Warszawa 2012.

Dolnicki B., Koncepcja powiatu metropolitalnego, „Samorząd Terytorialny” 2014, nr 7-8.

Dolnicki B., Marchaj R., Związek metropolitalny w województwie śląskim, „Samorząd Terytorialny" 2017, nr 7-8.

Dolnicki B., Samorząd terytorialny, Warszawa 2016.

54 GZM, Tradycyjna, lekka i jednoszynowa. To koncepcja Kolei Metropolitalnej, http://metropoliagzm.pl/blog/tradycyjna-lekka-i-jednoszynowa-to-koncepcja-kolei-metropolitalnej (dostęp 3.04.2019). 
Gawroński G., Kłoskowicz M., Stawowa A., Wycisk A., Zygmunt A., Metropolia w świetle opinii mieszkańców Górnoślaskiego Związu Metropolitalnego, w: Sposób na Metropolię. Idee a społeczne oczekiwania wobec projektu utworzenia ślasko-zagłębiowskiej metropolii, red. R. Pyka, Katowice 2010.

Glumińska-Pawlic J., w: Ustawa o samorzadzie powiatowym. Komentarz, red. B. Dolinicki, Warszawa 2007.

Góralczyk M., Panasiuk E., Przybyła M., Statystyczny obraz Górnośląsko-Zagłębiowskiej Metropolii w 2017 r., Katowice 2018.

Jastrzębska M., Finanse jednostek samorzadu terytorialnego, Warszawa 2012.

Juszczyk S., Zdolność kredytowa w ocenie banku na przykładzie matych i średnich przedsiębiorców,www.wne.sggw.pl/czasopisma/pdf/EIOGZ_2008_nr66_s17.pdf.

Kozera A., Samodzielność finansowa metropolii w Polsce w latach 2007-2015, „Studia Regionalne i Lokalne," 2018, nr 1 (71).

Moczko-Wdowczyk S., Mucha M., Podatek dochodowy od osób fizycznych. Komentarz, Warszawa 2005.

Ofiarska M., Problematyka budżetowa w ustawie o zwiazkach metropolitalnych, „Prawo Budżetowe Państwa i Samorządu” 2016, nr 2 (4).

Przywojska J., Warwas I., Innowacje w zarządzaniu publicznym i polityce społecznej. Wprowadzenie do problematyki, „Przedsiębiorczość i Zarządzanie” 2016, t. XVII, z. 4, cz. 2.

Pyka R., Górnośląsko-Zagłębiowska Metropolia jako innowacja w samorządzie terytorialnym. Szanse i wyzwania pierwszego w Polsce zwiazku metropolitalnego, „Studia Regionalne i Lokalne” 2018, nr 1 (71).

Rymarczyk W., 20 lat Komunikacyjnego Związu Komunalnego Górnoślaskiego Okręgu Przemysłowego, www.kzkgop.com.pl/public_media/fb/files/czasopisma/komunikacja/2011/kzk_3-2011.pdf.

Rynio D., Atrakcyjność lokalizacji inwestycji zagranicznych $w$ metropolii, w: Innowacyjna metropolia, konkurencyjny region, red. M. Słupińska, Łódź 2010.

Serwińska K., Narkiewicz-Tarłowska J., PIT. Komentarz praktyczny, Warszawa 2014.

Szajnowska-Wysocka A., Podstawy zorganizowania miast konurbacji górnoślaskiej, Katowice 1995.

\section{Akty prawne}

Konstytucja Rzeczypospolitej Polskiej z dnia 2 kwietnia 1997 r. (Dz.U. z 1997 r., nr 78, poz. 483).

Obwieszczenie Wojewody Śląskiego z dnia 12 czerwca 2015 r. w sprawie ogłoszenia zmiany statutu Komunikacyjnego Związku Komunalnego Górnośląskiego Okręgu Przemysłowego w Katowicach, poz. 3232. 
Uchwała Zarządu KZK GOP z dnia 7 listopada 2017 r. w sprawie przyjęcia projektu uchwały Zgromadzenia KZK GOP w sprawie planu finansowego na rok 2018, nr 63/2017.

Uchwała Zgromadzenia Górnośląsko-Zagłębiowskiej Metropolii z dnia 18 grudnia 2018 r. w sprawie uchwalenia Wieloletniej Prognozy Finansowej Górnośląsko-Zagłębiowskiego Metropolii na lata 2019-2030, nr XIII/78/2018.

Ustawa z dnia 13 listopada 2013 r. o dochodach jednostek samorządu terytorialnego (Dz.U. z 2019 r., poz. 525).

Ustawa z dnia 26 lipca 1991 r. o podatku dochodowym od osób fizycznych (Dz.U. z 2019 r., poz. 303).

Ustawa z dnia 9 marca 2017 r. o związku metropolitalnym w województwie śląskim (Dz.U. z 2017 r., poz. 730).

\section{Orzecznictwo}

Interpretacja indywidualna Dyrektora Izby Skarbowej w Łodzi z dnia 7 lutego 2012 r., IPTPB2/415-650/11-4/MP.

Wyrok WSA w Szczecinie z dnia 15 lutego 2018 r., I SA/Sz 1063/17.

\section{Źródla internetowe}

Bytom wystapił z KZK GOP, http://infobus.pl/bytom-bytom-wystapil-z-kzk-gop_more_7181. html.

Jaworzno występuje z GZM. Radni przyjęli uchwate w sprawie wyjścia z metropolii, http://katowice.wyborcza.pl/katowice/1,35063,20291839,jaworzno-wystepuje-z-gzm-radni-przyjeli-uchwale-w-sprawie-wyjscia.html.

Minister finansów ogłasza szczegóły obniżki PIT, www.forbes.pl/gospodarka/obnizkapit-kiedy-wejdzie-w-zycie-na-czym-bedzie-polegac/ljm5q1w.

Otwarcie Drogowej Trasy Średnicowej już w marcu!, https://conadrogach.pl/informacje/ gliwice-otwarcie-drogowej-trasy-srednicowej-juz-w-marcu.html.

Rządowy projekt ustawy o związu metropolitalnym w województwie śląskim, www. sejm.gov.pl/Sejm8.nsf/PrzebiegProc.xsp?nr=1211.

Tradycyjna, lekka i jednoszynowa. To koncepcja Kolei Metropolitalnej, http://metropoliagzm.pl/blog/tradycyjna-lekka-i-jednoszynowa-to-koncepcja-koleimetropolitalnej.

Wieloletnia prognoza finansowa Górnośląsko-Zagłębiowskiej Metropolii, https:// bip.katowice.eu/Lists/Dokumenty/Attachments/103371/w\%20sprawie\%20 
uchwalenia\%20Wieloletniej\%20Prognozy\%20Finansowej\%20Górnośląsko\%20

\%20Zagłębiowskiej\%20Metropolii\%20na\%201ata\%202017\%20-\%202020.pdf.

The impact of personal income tax in financing on the execution Metropolis GZM's tasks

\section{Summary}

Act of 9 March, 2017 on the metropolitan union in the Silesian voivodeship is a first regulation about the cooperation of the cities of the Upper Silesian conurbation. The metropolitan union has a particular nature in the Polish system of local self-government because it has its own tasks and has been covered by the statutory system of financing the activity. One of the sources of income is participation in personal income tax. It is an innovation solution which wasn't previously used by the Polish legislator. In view of the above, it is necessary to present the analysis of impact of personal income tax on financing the activity of Metropolis GZM in the context of chances, risks and social expectations.

Keywords: income tax, Metropolis GZM, conurbation, local self-government 